\title{
45. PLIOCENE PALEOCLIMATIC AND PALEOCEANOGRAPHIC HISTORY OF THE SOUTH ATLANTIC OCEAN: STABLE ISOTOPIC RECORDS FROM LEG 72 DEEP SEA DRILLING PROJECT HOLES 516A AND 5171
}

\author{
Kathleen A. Leonard, ${ }^{2}$ Department of Geology, University of South Carolina, Columbia, South Carolina \\ Douglas F. Williams, Department of Geology and Belle W. Baruch Institute, University of South Carolina, \\ Columbia, South Carolina \\ and \\ Robert C. Thunell, Department of Geology, University of South Carolina, Columbia, South Carolina
}

\begin{abstract}
Stable isotopic analyses $\left({ }^{18} \mathrm{O} /{ }^{16} \mathrm{O},{ }^{13} \mathrm{C} /{ }^{12} \mathrm{C}\right)$ of both benthic and planktonic foraminifers from DSDP Holes 516A and 517 appear to reflect changing paleoclimatic and paleoceanographic conditions in the South Atlantic Ocean during the Pliocene. The $\delta^{18} \mathrm{O}$ records of Cibicides wuellerstorfi and Globigerinoides sacculifer do not vary in phase with one another, indicating that the $\delta^{18} \mathrm{O}$ of $C$. wuellerstorfi is reflecting changing glacial ice volumes, but the $\delta^{18} \mathrm{O}$ of $G$. sacculifer is being influenced more by other factors, such as variable sea-surface temperatures and salinities.

A net depletion in ${ }^{18} \mathrm{O}$ and a series of very low-amplitude fluctuations characterize the late Pliocene planktonic $\delta^{18} \mathrm{O}$ record. The stability of this section may be related to increasing surface-water temperatures in middle southern latitudes during northern hemisphere glacial ice buildup caused by differences in the phasing of the orbital precessional cycle between the northern and southern hemispheres.

Hole $516 \mathrm{~A}$ is presently located in an area of strong $\delta^{13} \mathrm{C}$ gradients in the water column, and a similar situation probably prevailed during the Pliocene. A record of the difference between the $\delta^{13} \mathrm{C}$ of $C$. wuellerstorfi and $G$. sacculifer $\left(\Delta^{13} \mathrm{C}\right)$ reflects times of increased or decreased similarity in $\delta^{13} \mathrm{C}$ between Circumpolar Water and subtropical surface waters throughout the Pliocene. Periods of increased or decreased $\Delta^{13} \mathrm{C}$ may reflect: 1) changes in water mass boundaries because of expansion or contraction of a particular water mass, or 2) changes in the partitioning of ${ }^{13} \mathrm{C}$ within the various components of the global carbon reservoir. These changes may be associated with glacial/interglacial climatic changes, such as the initiation of northern hemisphere glaciation.
\end{abstract}

\section{INTRODUCTION}

Paleoclimatic and paleoceanographic trends and variations through time can be effectively studied through changes in the oxygen and carbon stable isotopic composition of foraminifers in deep-sea sediments (Emiliani, 1955, 1966; Savin, 1977; Shackleton and Opdyke, 1977). Oxygen and carbon stable isotopic analysis of sediments recovered at Holes 516A and 517 during DSDP Leg 72 in the western South Atlantic Ocean provide a relatively continuous history of the Pliocene Epoch from 4.6 to $1.8 \mathrm{Ma}$. Several factors affect the ${ }^{18} \mathrm{O} /{ }^{16} \mathrm{O}$ ratio of calcite precipitated from seawater, including: 1) temperature, 2) the isotopic composition of seawater, which is affected by changing glacial ice volume, 3) salinity, 4) depth habitat, 5) vital effects, and 6) partial dissolution or diagenesis. The influences of depth habitat and vital effects are minimized by analyzing a limited size fraction of a particular species. The excellent preservation of the foraminifers at Holes 516A and 517 indicate that diagenesis or dissolution is negligible. Therefore, temperature, ice volume, and salinity should be the three major factors affecting variations in the $\delta^{18} \mathrm{O}$ of foraminifers.

\footnotetext{
${ }^{1}$ Barker, P. F., Carlson, R. L., Johnson, D. A., et al., Init. Repts. DSDP, 72: Washington (U.S. Govt. Printing Office).

2 Present address: Marathon Oil Company, Houston, Texas.
}

The oxygen isotopic variation in the composition of post-Miocene benthic foraminifers is considered to reflect changes in glacial ice volume (Shackleton and Kennett, 1975; Savin et al., 1975; Woodruff et al., 1981). The effects of temperature and salinity on oxygen isotopic fractionation in benthic foraminifers remain relatively constant because the bottom waters are formed from high-latitude surface waters of relatively constant temperature and salinity. Oxygen isotopic variations in post-Miocene planktonic foraminifers also predominantly reflect changing glacial ice volumes, as well as the more variable surface-water temperatures and salinities (van Donk, 1976; Savin, 1977).

The carbon isotopic composition of calcite precipitated from seawater appears to vary with the ${ }^{13} \mathrm{C} /{ }^{12} \mathrm{C}$ ratio of total dissolved carbon dioxide $\left(\mathrm{\Sigma CO}_{2}\right)$. Total dissolved carbon dioxide is approximately $89 \%$ dissolved bicarbonate (Kroopnick, 1974); therefore, variations in the $\delta^{13} \mathrm{C}$ of foraminiferal calcite should dominantly reflect variations in the $\delta^{13} \mathrm{C}$ of dissolved $\mathrm{HCO}_{3}^{-}$. The paleoceanographic changes affecting $\delta^{13} \mathrm{C}$ variations of dissolved bicarbonate are not well understood, but several theories have been proposed. Shackleton (1977) postulated that carbon isotopic events in the late Pleistocene are caused by changes in the volume of the continental biomass, which are related to the glacial/interglacial aridity cycles. Broecker (1982) related variations in the $\delta^{13} \mathrm{C}$ of dissolved $\mathrm{HCO}_{3}^{-}$to the effects of glacial/in- 
terglacial sea-level fluctuations on the volume of organic matter buried in shelf sediments and the associated removal of phosphate $\left(\mathrm{PO}_{4}\right)$ from the oceans. Scholle and Arthur (1980) have related variations in the $\delta^{13} \mathrm{C}$ of carbonate precipitated from seawater to organic carbon burial rates in deep-sea sediments. Times of increased organic carbon burial would be times of increased $\delta^{13} \mathrm{C}$ in dissolved bicarbonate. Duplessy and others (1980) have presented evidence that $\delta^{13} \mathrm{C}$ variations in the Atlantic are a result of changing circulation rates, caused by a possible decrease in the production of North Atlantic Deep Water (NADW) during northern hemisphere glacial events. Variations in the degree of stratification of the water column and its effects on upwelling rates could also influence the $\delta^{13} \mathrm{C}$ values of surface waters.

Studies of carbon isotopic records have proposed different combinations of the above theories to explain paleoceanographic events reflected in excursions of the $\delta^{13} \mathrm{C}$ record of calcite precipitated from seawater. Bender and Keigwin (1979) observed that a significant negative shift in $\delta^{13} \mathrm{C}$ occurred during the late Miocene. They related this ${ }^{13} \mathrm{C}$ decrease to a decrease in upwelling rates or to changes in abyssal circulation. Vincent and others (1980) also noted that this negative late Miocene $\delta^{13} \mathrm{C}$ event had occurred, and they proposed that the ${ }^{13} \mathrm{C}$ depletion reflected an organic carbon transfer to the oceans from shelf areas exposed during regressions. This transfer may have been accompanied by a change in deep circulation patterns and ocean fertility.

Changes in oceanic circulation patterns or rates should also be reflected in the distribution of various water mass properties. This detailed comparison of Pliocene benthic and planktonic stable isotopic records from DSDP Hole 516A and planktonic isotope data from DSDP Site 517 attempts to determine if the $\delta^{18} \mathrm{O}$ and $\delta^{13} \mathrm{C}$ fluctuations in and between Circumpolar Water (CPW) and surface waters in the South Atlantic are related to significant climatic or oceanographic events.

\section{SITE LOCATION AND HYDROGRAPHY}

DSDP Holes 516A and 517 were drilled with the hydraulic piston corer (HPC) during Leg 72 in the western South Atlantic Ocean. Hole $516 \mathrm{~A}$ is located at $30^{\circ} 17^{\prime} \mathrm{S}$, $35^{\circ} 17^{\prime} \mathrm{W}$. Site 517 is located to the west of $516 \mathrm{~A}$ at $30^{\circ} 56^{\prime} \mathrm{S}, 38^{\circ} 02^{\prime} \mathrm{W}$. Both sites are located on the Rio Grande Rise (Fig. 1). The Rio Grande Rise is a major aseismic ridge whose origin is most likely related to fracture zones associated with the Mid-Atlantic Ridge spreading center. These fracture zones were probably active during the initial rifting of the South Atlantic Ocean during the Early Cretaceous (Francheteau and LePichon, 1972).

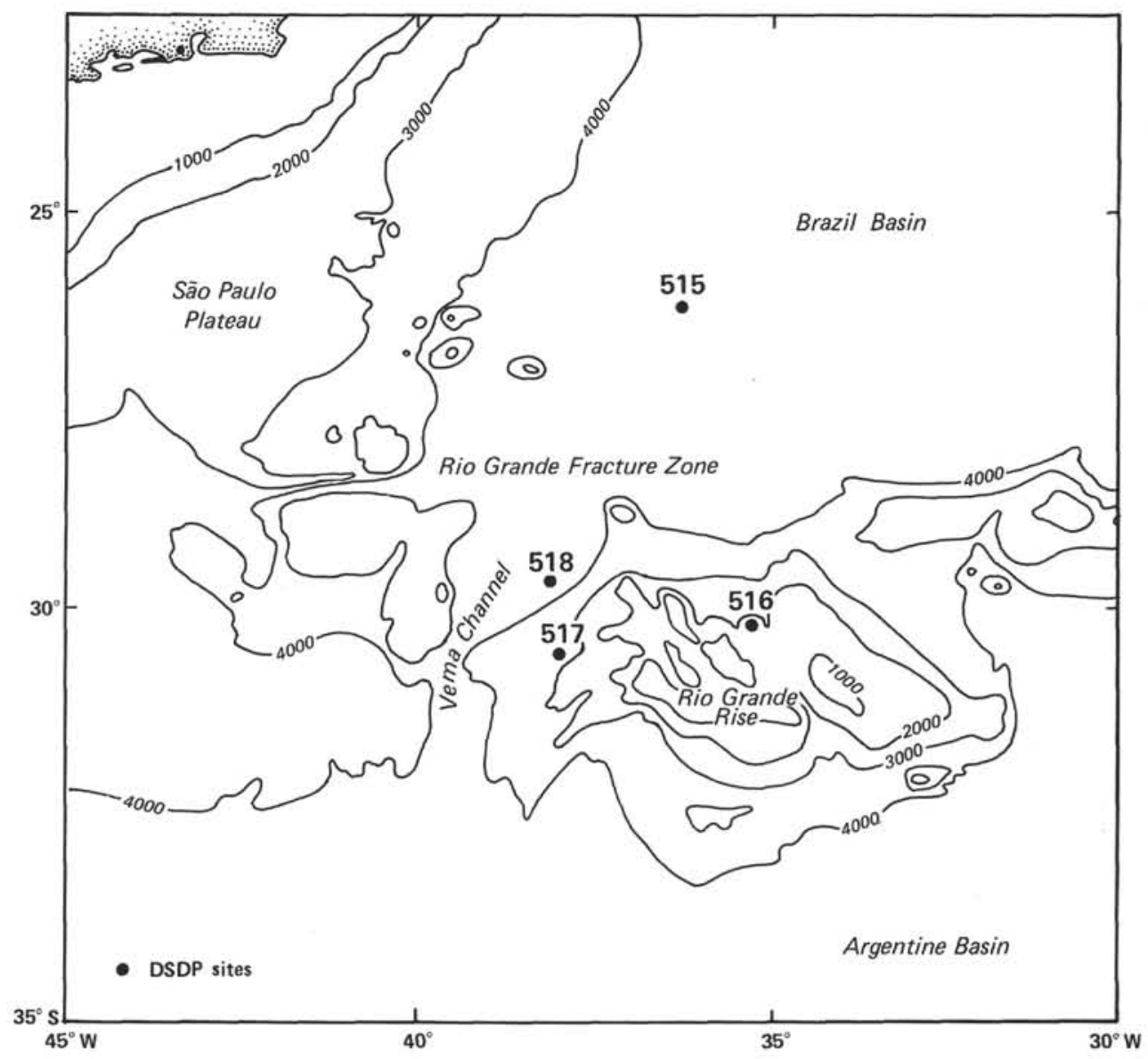

Figure 1. The location of DSDP Holes 516A and 517, which were hydraulically piston cored during Leg 72 on the Rio Grande Rise in the South Atlantic Ocean. 
At a water depth of $1313 \mathrm{~m}$, Hole 516A lies within the transition between Antarctic Intermediate Water (AAIW) and the upper branch of CPW. The deeper site, 517 $(2963 \mathrm{~m})$, lies within NADW and is mainly a product of several sources in the northernmost Atlantic. Where southward-flowing NADW meets CPW flowing north, NADW separates the CPW into distinct upper and lower branches (Reid et al., 1977; Broecker and Takahashi, 1980). All of these water masses can be traced and distinguished based on unique characteristics derived from their original source (Broecker and Takahashi, 1980). Particular water masses also exhibit characteristic ranges in $\delta^{18} \mathrm{O}$ and $\delta^{13} \mathrm{C}$ (Fig. 2, after Kroopnick, 1980a, b). Data from GEOSECS Stations 59 and 60 and Cato Expedition Stations 10 and 14 in the western South Atlantic indicate that Hole $516 \mathrm{~A}$ is presently situated within an area of strong hydrographic gradients at the base of the thermocline within both the oxygen and salinity minima and within a nutrient $\left(\mathrm{PO}_{4} \overline{\text { and }} \mathrm{NO}_{3}\right)$ maximum (Reid et al., 1977). The depth of Hole 516A $(1313 \mathrm{~m})$ is also associated with a strong $\delta^{13} \mathrm{C}$ gradient centered at the base of the thermocline (Kroopnick, 1980a).

Apparently, present-day Atlantic surface circulation patterns became established during the Pliocene after the emergence of the Panama isthmus (Berggren and Hollister, 1977; Keigwin, 1978, 1979; Keigwin, 1982). Backtracking indicates that the Rio Grande Rise had subsided to approximately its present water depth by the Pliocene (Thiede, 1977; Barker, this volume). Therefore, Pliocene hydrography and circulation in the South Atlantic are assumed to have been very similar to the modern patterns at Hole 516A. Because of its location within an area of strong hydrographic gradients, Hole 516A should be a sensitive indicator of expansions or contractions of the NADW, CPW, and AAIW during the Pliocene.

\section{METHODS}

\section{Isotopic Analyses}

The planktonic foraminiferal species, Globigerinoides sacculifer, was selected for oxygen and carbon isotopic analyses from the 300 -to355 -micron size fraction at intervals of $50 \mathrm{~cm}$ or less from the Pliocene sections of Holes 516A and 517. The isotopic samples were limited to a particular morphotype of $G$. sacculifer, a compact form that does not possess a large irregular sac as a final chamber. The benthic foraminiferal species, Cibicides (Planulina) wuellerstorfi from the $>150$-micron size fraction was also analyzed from the Hole 516A samples. In a few samples, this species was not abundant enough for isotopic analysis. When this was the case, C. kullenbergi was analyzed. Analyses of both benthic species from the same samples indicate that these two species are isotopically similar and may be used interchangeably within experimental error (Table 1) (Duplessy et al., 1980; Woodruff et al., 1981; Keigwin, 1982). The benthic foraminifers were also sampled every $50 \mathrm{~cm}$ or less at Hole $516 \mathrm{~A}$.

In general, foraminifers do not deposit their calcite tests in oxygen and carbon isotopic equilibrium with seawater. A number of species, however, exhibit a consistent offset relative to the $\delta^{18} \mathrm{O}$ of ambiest seawater and the $\delta^{18} \mathrm{O}$ of dissolved bicarbonate. Both $G$. sacculifer (Williams et al., 1977) and C. wuellerstorfi (Graham et al., 1981; Belanger et al., 1981) appear to deposit their tests close to, but consistently offset from, equilibrium. This characteristic allows researchers to base the qualitative paleoclimatic and paleoceanographic interpretations on the isotopic variation of these species through time.

The samples for isotopic analysis were processed and analyzed according to the techniques of Williams and others (1977). Each sample was ultrasonically cleaned in deionized water. Then the benthic foraminifers were lightly crushed, and both planktonic and benthic foraminifers were roasted in vacuo at $380^{\circ} \mathrm{C}$ for 60 minutes. The oxygen and carbon isotopic composition of the $\mathrm{CO}_{2}$ gas (derived by reacting the samples with $100 \%$ phosphoric acid at $50^{\circ} \mathrm{C}$ ) was analyzed by use of a VG Micromass $602 \mathrm{D}$ isotope ratio-mass spectrometer.

The benthic and planktonic isotopic results (Tables 1,2, and 3) are reported in terms of the PDB standard by the repeated analysis of the two isotopic standards, NBS-20 and TKL-1. The $\delta^{18} \mathrm{O}$ and $\delta^{13} \mathrm{C}$ values for NBS-20 with respect to PDB are $4.18 \%$ and $-1.06 \%$, respectively (Craig, 1957). The $\delta^{18} \mathrm{O}$ and $\delta^{13} \mathrm{C}$ values for TKL-1 are -4.26 and $-1.69 \%$, respectively (Blattner and Hulston, 1978). Analytical precision based on the routine analysis of a standard carbonate powder is $\pm 0.09 \%_{0}$ for $\delta^{18} \mathrm{O}$ and $\pm 0.07 \%_{0}$ for $\delta^{13} \mathrm{C}$ The average standard deviation from the mean $(1 \alpha)$ for replicate analyses of benthic foraminiferal

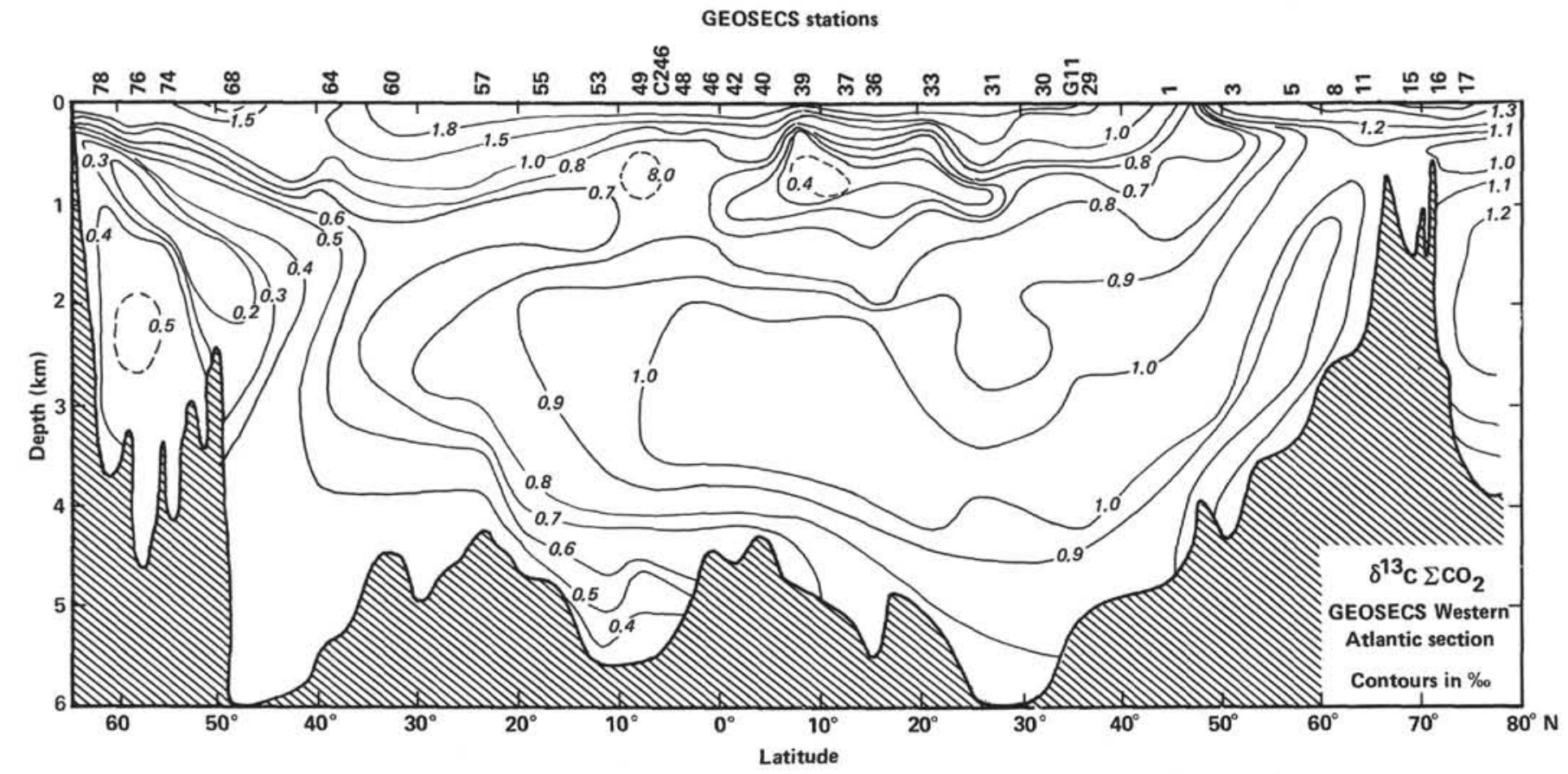

Figure 2. The present-day distribution of the $\delta^{13} \mathrm{C}$ of $\Sigma \mathrm{\Sigma O}_{2}(\%)$ in the western Atlantic Ocean (from Kroopnick, 1980a). 
K. A. LEONARD, D. F. WILLIAMS, R. C. THUNELL

Table 1. Oxygen and carbon isotopic results of Cibicides wuellerstorfi from Hole 516A.

\begin{tabular}{|c|c|c|c|}
\hline $\begin{array}{l}\text { Core-section } \\
\text { (interval in cm) }\end{array}$ & $\begin{array}{l}\text { Age } \\
(\mathrm{Ma})^{\mathrm{a}}\end{array}$ & $\begin{array}{c}\delta^{18} \mathrm{O} \\
(\mathrm{PDB} \%)\end{array}$ & $\begin{array}{c}\delta^{13} \mathrm{C} \\
\text { (PDB\%) }\end{array}$ \\
\hline $3-2,50-52$ & 2.71 & 2.88 & 1.13 \\
\hline $3-2,70-72$ & 2.73 & 2.17 & 0.42 \\
\hline $3-2,120-122$ & 2.77 & 2.76 & 0.87 \\
\hline $3-3,20-22$ & 2.80 & 2.91 & 0.85 \\
\hline $3-3,44-46$ & 2.82 & 2.62 & 0.89 \\
\hline $4-1,4-6$ & 2.90 & 2.96 & 0.87 \\
\hline $4-1,4-6$ & 2.90 & 2.30 & 0.83 \\
\hline $4-1,4-6$ & 2.90 & 2.77 & 0.74 \\
\hline $4-1,20-22$ & 2.91 & 2.86 & 0.90 \\
\hline $4-1,20-22$ & 2.91 & 2.89 & 0.75 \\
\hline $4-1,70-72$ & 2.95 & 2.86 & 1.07 \\
\hline $4-1,120-122$ & 2.99 & 2.71 & 0.86 \\
\hline $4-2,20-22$ & 3.02 & 2.43 & 0.62 \\
\hline $4-2,70-72$ & 3.06 & 2.43 & 0.57 \\
\hline $4-2,100-102$ & 3.08 & 2.70 & 1.15 \\
\hline $4-2,100-102$ & 3.08 & 2.52 & 1.07 \\
\hline $4-2,120-122$ & 3.10 & 2.53 & 0.76 \\
\hline $4-3,20-22$ & 3.14 & 2.71 & 0.71 \\
\hline $4-3,70-72$ & 3.17 & 2.43 & 0.51 \\
\hline $4-3,94-96$ & 3.19 & 2.49 & 0.86 \\
\hline $5-1,10-12$ & 3.23 & 2.44 & 1.01 \\
\hline $5-1,20-22$ & 3.23 & 2.20 & 0.89 \\
\hline $5-1,70-72$ & 3.27 & 2.36 & 0.68 \\
\hline $5-1,120-122$ & 3.30 & 2.47 & 0.80 \\
\hline $5-2,20-22$ & 3.34 & 2.23 & 0.79 \\
\hline $5-2,70-72$ & 3.37 & 2.32 & 0.69 \\
\hline $5-2,120-122$ & 3.41 & 2.15 & 0.60 \\
\hline $5-3,20-22$ & 3.48 & 2.23 & 0.50 \\
\hline $5-3,34-36$ & 3.50 & 2.37 & 0.91 \\
\hline $5-3,34-36$ & 3.50 & 2.20 & 0.75 \\
\hline $5-3,64-66$ & 3.54 & 2.46 & 0.97 \\
\hline $5-3,70-72$ & 3.55 & 2.35 & 0.87 \\
\hline $5-3,80-82$ & 3.57 & 2.40 & 1.09 \\
\hline $5-3,80-82$ & 3.57 & 2.18 & 0.90 \\
\hline $5-3,98-100$ & 3.59 & 2.37 & 1.02 \\
\hline $6-1,7-9$ & 3.66 & 2.50 & 0.89 \\
\hline $6-1,20-22$ & 3.68 & 2.24 & 0.58 \\
\hline $6-1,50-52$ & 3.72 & 2.11 & 0.86 \\
\hline $6-1,50-52$ & 3.72 & 2.31 & 0.83 \\
\hline $6-1,70-72$ & 3.75 & 2.34 & 0.78 \\
\hline $6-1,70-72$ & 3.75 & 1.90 & 0.78 \\
\hline $6-1,70-72$ & 3.75 & 2.25 & 0.75 \\
\hline $6-1,120-122$ & 3.82 & 2.25 & 0.66 \\
\hline $6-2,20-22$ & 3.84 & 2.44 & 0.77 \\
\hline $6-2,70-72$ & 3.87 & 2.11 & 0.60 \\
\hline $6-2,120-122$ & 3.89 & 2.27 & 0.72 \\
\hline $6-3,20-22$ & 3.91 & 2.34 & 0.67 \\
\hline $6-3,70-72$ & 3.93 & 2.37 & 0.70 \\
\hline $6-3,120-122$ & 3.96 & 2.27 & 0.64 \\
\hline $7-1,20-22$ & 3.98 & 2.40 & 0.57 \\
\hline $7-1,70-72$ & 4.00 & 1.97 & 0.78 \\
\hline $7-1,120-122$ & 4.02 & 2.18 & 0.71 \\
\hline $7-2,20-22$ & 4.05 & 2.16 & 0.84 \\
\hline $7-2,70-72$ & 4.07 & 2.18 & 0.66 \\
\hline $7-2,120-122$ & 4.09 & 1.90 & 0.73 \\
\hline $7-3,20-22$ & 4.11 & 1.98 & 0.77 \\
\hline $7-3,70-72$ & 4.14 & 2.04 & 0.85 \\
\hline $7-3,70-72^{b}$ & 4.14 & 2.27 & 0.49 \\
\hline $8-1,20-22$ & 4.18 & 2.26 & 0.58 \\
\hline $8-1,20-22^{b}$ & 4.18 & 2.23 & 0.60 \\
\hline $8-1,70-72$ & 4.20 & 2.33 & 0.79 \\
\hline $8-1,120-122$ & 4.22 & 2.08 & 0.99 \\
\hline $8-1,120-122^{b}$ & 4.22 & 2.18 & 0.85 \\
\hline $8-2,20-22^{b}$ & 4.25 & 2.38 & 0.83 \\
\hline $8-2,70-72$ & 4.27 & 2.24 & 0.87 \\
\hline $8-2,70-72^{b}$ & 4.27 & 2.27 & 0.72 \\
\hline $8-2,120-122$ & 4.29 & 2.15 & 1.06 \\
\hline $8-3,20-22$ & 4.31 & 2.29 & 0.79 \\
\hline $8-3,20-22$ & 4.31 & 2.33 & 0.75 \\
\hline $8-3,70-72$ & 4.31 & 2.37 & 0.95 \\
\hline $8-3,120-122$ & 4.36 & 2.42 & 1.02 \\
\hline $9-1,20-22$ & 4.38 & 2.77 & 0.76 \\
\hline $9-1,70-72^{b}$ & 4.40 & 2.34 & 0.36 \\
\hline $9-1,120-122^{b}$ & 4.43 & 2.31 & 0.64 \\
\hline $9-1,138-140$ & 4.43 & 3.01 & 0.96 \\
\hline $9-1,138-140$ & 4.43 & 3.11 & 0.82 \\
\hline $9-2,10-12$ & 4.44 & 3.06 & 0.54 \\
\hline $9-2,20-22$ & 4.44 & 2.30 & 0.90 \\
\hline $9-2,70-72$ & 4.47 & 2.26 & 0.90 \\
\hline $9-2,120-122$ & 4.51 & 2.11 & 0.82 \\
\hline $9-3,20-22$ & 4.54 & 2.20 & 1.01 \\
\hline $9-3,70-72$ & 4.58 & 2.29 & 0.87 \\
\hline $9-3,120-122$ & 4.61 & 2.12 & 0.86 \\
\hline
\end{tabular}

Table 2. Oxygen and carbon isotopic results of Globigerinoides sacculifer from Hole 516A.

\begin{tabular}{|c|c|c|c|}
\hline $\begin{array}{l}\text { Core-section } \\
\text { (interval in } \mathrm{cm} \text { ) }\end{array}$ & $\underset{(\mathrm{Ma})^{\mathrm{a}}}{\mathrm{Age}}$ & $\begin{array}{c}\delta^{18} \mathrm{O} \\
\left(\mathrm{PDB} \%{ }^{18}\right)\end{array}$ & $\begin{array}{c}\delta^{13} \mathrm{C} \\
\left(\mathrm{PDB} \%_{0}\right)\end{array}$ \\
\hline $3-2,40-42$ & 2.70 & 0.33 & 2.03 \\
\hline $3-2,50-52$ & 2.71 & 0.39 & 2.09 \\
\hline $3-2,70-72$ & 2.73 & 0.31 & 1.64 \\
\hline $3-2,70-72$ & 2.73 & 0.61 & 1.93 \\
\hline $3-2,70-72$ & 2.73 & 0.30 & 1.68 \\
\hline $3-2,120-122$ & 2.77 & 0.22 & 1.92 \\
\hline $3-3,20-22$ & 2.80 & 0.33 & 1.91 \\
\hline $3-3,20-22$ & 2.80 & 0.41 & 1.82 \\
\hline $3-3,20-22$ & 2.80 & 0.53 & 1.88 \\
\hline $3-3,44-46$ & 2.82 & 0.39 & 2.02 \\
\hline $4-1,4-6$ & 2.90 & 0.23 & 1.93 \\
\hline $4-1,20-22$ & 2.91 & 0.05 & 1.74 \\
\hline $4-1,20-22$ & 2.91 & 0.25 & 2.03 \\
\hline $4-1,70-72$ & 2.95 & 0.14 & 1.71 \\
\hline $4-1,120-122$ & 2.99 & 0.63 & 1.80 \\
\hline $4-1,120-122$ & 2.99 & 0.41 & 1.98 \\
\hline $4-2,20-22$ & 3.02 & 0.43 & 1.98 \\
\hline $4-2,20-22$ & 3.02 & 0.21 & 1.73 \\
\hline $4-2,70-72$ & 3.06 & 0.10 & 1.91 \\
\hline $4-2,70-72$ & 3.06 & 0.27 & 1.69 \\
\hline $4-2,100-102$ & 3.08 & 0.32 & 1.94 \\
\hline $4-2,120-122$ & 3.10 & 0.28 & 2.00 \\
\hline $4-2,120-122$ & 3.10 & 0.28 & 1.83 \\
\hline $4-2,120-122$ & 3.10 & 0.79 & 1.83 \\
\hline $4-2,120-122$ & 3.10 & 0.45 & 1.78 \\
\hline $4-3,20-22$ & 3.14 & 0.35 & 1.84 \\
\hline $4-3,20-22$ & 3.14 & 0.58 & 1.98 \\
\hline $4-3,70-72$ & 3.17 & 0.13 & 2.07 \\
\hline $4-3,94-96$ & 3.19 & 0.13 & 2.11 \\
\hline $5-1,10-12$ & 3.23 & -0.09 & 2.22 \\
\hline $5-1,10-12$ & 3.23 & 0.31 & 1.91 \\
\hline $5-1,20-22$ & 3.23 & 0.21 & 1.75 \\
\hline $5-1,70-72$ & 3.27 & 0.29 & 2.31 \\
\hline $5-1,120-122$ & 3.30 & 0.36 & 2.13 \\
\hline $5-2,20-22$ & 3.34 & 0.44 & 2.08 \\
\hline $5-2,70-72$ & 3.37 & 0.57 & 2.22 \\
\hline $5-2,120-122$ & 3.41 & 0.58 & 2.08 \\
\hline $5-3,20-22$ & 3.48 & 0.54 & 2.01 \\
\hline $5-3,34-36$ & 3.50 & 0.08 & 1.94 \\
\hline $5-3,64-66$ & 3.54 & 0.31 & 1.88 \\
\hline $5-3,70-72$ & 3.55 & 0.64 & 2.10 \\
\hline $5-3,80-82$ & 3.57 & 0.56 & 2.07 \\
\hline $5-3,98-100$ & 3.59 & 0.44 & 1.86 \\
\hline $6-1,7-9$ & 3.66 & 0.26 & 1.83 \\
\hline $6-1,20-22$ & 3.68 & 0.57 & 2.12 \\
\hline $6-1,20-22$ & 3.68 & 0.62 & 1.87 \\
\hline $6-1,50-52$ & 3.72 & 0.28 & 1.99 \\
\hline $6-1,70-72$ & 3.75 & 0.31 & 2.12 \\
\hline $6-1,120-122$ & 3.82 & 0.41 & 1.88 \\
\hline $6-2,20-22$ & 3.84 & 0.26 & 1.62 \\
\hline $6-2,70-72$ & 3.87 & 0.16 & 1.84 \\
\hline $6-2,120-122$ & 3.89 & 0.17 & 1.92 \\
\hline $6-3,20-22$ & 3.91 & 0.23 & 1.93 \\
\hline $6-3,70-72$ & 3.93 & 0.21 & 2.30 \\
\hline $6-3,120-122$ & 3.96 & 0.15 & 2.15 \\
\hline $7-1,20-22$ & 3.98 & 0.26 & 2.12 \\
\hline $7-1,70-72$ & 4.00 & 0.31 & 2.10 \\
\hline $7-1,120-122$ & 4.02 & 0.11 & 1.98 \\
\hline $7-2,20-22$ & 4.05 & 0.14 & 2.24 \\
\hline $7-2,20-22$ & 4.05 & 0.15 & 2.24 \\
\hline $7-2,20-22$ & 4.07 & 0.30 & 1.96 \\
\hline $7-2,120-122$ & 4.09 & 0.19 & 2.04 \\
\hline $7-2,120-122$ & 4.09 & 0.41 & 2.09 \\
\hline $7-3,20-22$ & 4.11 & 0.30 & 2.17 \\
\hline $7-3,70-72$ & 4.14 & 0.40 & 2.11 \\
\hline $8-1,20-22$ & 4.18 & 0.41 & 2.16 \\
\hline $8-1,70-72$ & 4.20 & 0.43 & 1.98 \\
\hline $8-1,120-122$ & 4.22 & 0.37 & 2.41 \\
\hline $8-2,20-22$ & 4.25 & 0.40 & 1.96 \\
\hline $8-2,70-72$ & 4.27 & 0.21 & 1.96 \\
\hline $8-2,120-122$ & 4.29 & 0.65 & 2.13 \\
\hline $8-3,20-22$ & 4.31 & 0.40 & 2.25 \\
\hline $8-3,70-72$ & 4.34 & 0.51 & 2.42 \\
\hline $8-3,120-122$ & 4.36 & 0.19 & 2.43 \\
\hline $9-1,20-22$ & 4.38 & 0.14 & 2.38 \\
\hline $9-1,70-72$ & 4.40 & 0.29 & 2.18 \\
\hline $9-1,120-122$ & 4.43 & 0.25 & 2.54 \\
\hline $9-1,138-140$ & 4.43 & 0.22 & 1.94 \\
\hline $9-2,10-12$ & 4.44 & 0.41 & 1.97 \\
\hline $9-2,20-22$ & 4.44 & 0.09 & 2.47 \\
\hline $9-2,70-72$ & 4.47 & 0.13 & 2.58 \\
\hline $9-2,98-100$ & 4.49 & -0.06 & 2.31 \\
\hline $9-2,120-122$ & 4.51 & 0.10 & 2.40 \\
\hline $9-3,10-12$ & 4.54 & 0.19 & 2.19 \\
\hline $9-3,20-22$ & 4.54 & 0.41 & 2.62 \\
\hline $9-3,34-36$ & 4.55 & 0.16 & 2.23 \\
\hline $9-3,54-56$ & 4.57 & 0.05 & 2.15 \\
\hline $9-3,70-72$ & 4.58 & 0.30 & 2.45 \\
\hline $9-3,120-122$ & 4.61 & 0.20 & 2.41 \\
\hline
\end{tabular}


Table 3. Oxygen and carbon isotopic results of Globigerinoides sacculifer from Site 517.

\begin{tabular}{|c|c|c|c|}
\hline $\begin{array}{c}\text { Core-section } \\
\text { (interval in cm) }\end{array}$ & $\begin{array}{l}\text { Age } \\
(\mathrm{Ma})^{\mathrm{a}}\end{array}$ & $\begin{array}{c}\delta^{18} \mathrm{O} \\
\left(\mathrm{PDB} \%_{0}\right)\end{array}$ & $\begin{array}{c}\delta^{13} \mathrm{C} \\
\left(\mathrm{PDB} \%_{0}\right)\end{array}$ \\
\hline $7-1,20-22$ & 1.76 & -0.04 & 1.86 \\
\hline $7-1,70-72$ & 1.80 & -0.10 & 2.04 \\
\hline $7-1,120-122$ & 1.84 & -0.01 & 1.65 \\
\hline $7-2,20-22$ & 1.88 & 0.04 & 2.00 \\
\hline $7-2,70-72$ & 1.93 & -0.08 & 2.12 \\
\hline $7-2,120-122$ & 1.97 & 0.02 & 1.94 \\
\hline $7-3,20-22$ & 2.01 & 0.04 & 2.18 \\
\hline $7-3,70-72$ & 2.05 & -0.10 & 1.79 \\
\hline $8-1,20-22$ & 2.13 & -0.09 & 2.10 \\
\hline $8-1,20-22$ & 2.13 & 0.12 & 1.78 \\
\hline $8-1,70-72$ & 2.17 & -0.09 & 1.91 \\
\hline $8-1,70-72$ & 2.17 & -0.05 & 1.57 \\
\hline $8-1,120-122$ & 2.22 & -0.12 & 2.20 \\
\hline $8-1,120-122$ & 2.22 & 0.09 & 1.81 \\
\hline $8-2,20-22$ & 2.26 & -0.09 & 1.87 \\
\hline $8-2,70-72$ & 2.30 & 0.11 & 2.19 \\
\hline $8-2,120-122$ & 2.35 & 0.27 & 1.79 \\
\hline $8-3,20-22$ & 2.40 & 0.39 & 1.94 \\
\hline $8-3,70-72$ & 2.44 & 0.20 & 1.77 \\
\hline $8-3,120-122$ & 2.49 & 0.14 & 1.93 \\
\hline $9-1,20-22$ & 2.53 & 0.05 & 2.03 \\
\hline $9-1,70-72$ & 2.58 & 0.12 & 2.28 \\
\hline $9-1,70-72$ & 2.58 & 0.29 & 2.01 \\
\hline $9-1,120-122$ & 2.62 & 0.28 & 1.94 \\
\hline $9-1,120-122$ & 2.62 & 0.36 & 1.94 \\
\hline $9-2,20-22$ & 2.67 & 0.43 & 2.00 \\
\hline $9-2,20-22$ & 2.67 & 0.53 & 1.98 \\
\hline $9-2,70-72$ & 2.72 & -0.20 & 2.41 \\
\hline $9-2,70-72$ & 2.72 & -0.14 & 2.11 \\
\hline $9-3,20-22$ & 2.81 & 0.04 & 2.17 \\
\hline $9-3,20-22$ & 2.81 & 0.16 & 2.09 \\
\hline $9-3,20-22$ & $2.8 \mathrm{I}$ & 0.40 & 2.09 \\
\hline $9-3,20-22$ & 2.81 & 0.11 & 2.03 \\
\hline $9-3,20-22$ & 2.81 & 0.11 & 2.13 \\
\hline $9-3,70-72$ & 2.86 & -0.11 & 2.13 \\
\hline $9-3,120-122$ & 2.91 & 0.03 & 2.26 \\
\hline $10-2,20-22$ & 2.96 & 0.08 & 2.11 \\
\hline $10-2,70-72$ & 2.97 & 0.02 & 2.04 \\
\hline $10-2,120-122$ & 2.99 & 0.09 & 2.03 \\
\hline $10-3,20-22$ & 3.00 & 0.17 & 1.92 \\
\hline $10-3,70-72$ & 3.01 & 0.07 & 2.02 \\
\hline $10-3,70-72$ & 3.01 & 0.55 & 2.10 \\
\hline $10-3,70-72$ & 3.01 & 0.02 & 1.87 \\
\hline $11-2,20-22$ & 3.07 & 0.05 & 1.93 \\
\hline $11-2,70-72$ & 3.09 & 0.19 & 2.21 \\
\hline $11-2,120-122$ & 3.10 & -0.11 & 2.31 \\
\hline $11-3,20-22$ & 3.11 & -0.08 & 2.15 \\
\hline $11-3,70-72$ & 3.13 & 0.08 & 2.14 \\
\hline $11-3,120-122$ & 3.14 & -0.13 & 2.20 \\
\hline $12-1,20-22$ & 3.15 & 0.20 & 2.13 \\
\hline $12-1,70-72$ & 3.16 & 0.29 & 1.90 \\
\hline $12-1,120-122$ & 3.18 & 0.01 & 1.69 \\
\hline $12-1,120-122$ & 3.18 & 0.02 & 1.73 \\
\hline $12-2,20-22$ & 3.19 & 0.34 & 2.08 \\
\hline $12-2,70-72$ & 3.20 & 0.62 & 1.94 \\
\hline $12-2,120-122$ & 3.21 & 0.22 & 2.37 \\
\hline $12-2,120-122$ & 3.21 & 0.02 & 2.33 \\
\hline $12-3,20-22$ & 3.23 & 0.57 & 2.17 \\
\hline $12-3,20-22$ & 3.23 & 0.49 & 2.05 \\
\hline $12-3,20-22$ & 3.23 & 0.44 & 2.10 \\
\hline $12-3,70-72$ & 3.24 & 0.49 & 2.07 \\
\hline $12-3,70-72$ & 3.24 & 0.31 & 2.18 \\
\hline $12-3,120-122$ & 3.25 & 0.35 & 1.71 \\
\hline $12-3,120-122$ & 3.25 & 0.10 & 1.64 \\
\hline
\end{tabular}

samples is \pm 0.11 for $\delta^{18} \mathrm{O}$ and \pm 0.05 for $\delta^{13} \mathrm{C}$. The $1 \alpha$ values for planktonic analyses are $\pm 0.10 \%$ for $\delta^{18} \mathrm{O}$ and $\pm 0.09 \%$ for $\delta^{13} \mathrm{C}$.

\section{Stratigraphy of Holes 516A and 517}

The planktonic foraminiferal assemblages at Holes 516A and 517 are well preserved and exhibit little evidence of mixing, reworking, or severe dissolution. The planktonic foraminiferal zonation established for the Rio Grande Rise region of the South Atlantic Ocean by Berggren (1977) was used to zone both sites biostratigraphically. The time framework is based on extrapolation between planktonic foraminiferal biostratigraphic datum levels (Berggren, 1977) that have previously been correlated with the paleomagnetic time scale (Ryan et al., 1974; Saito et al., 1975). The absolute ages assigned to the biostrati- graphic events are those suggested by Thunell (1981), which are based on the revised polarity time scales of McDougall (1977) and Mankinen and Dalrymple (1979). The Pliocene/Pleistocene boundary is assumed to fall within the Olduvai normal event (Haq et al., 1977) and is assigned a date of approximately $1.80 \mathrm{Ma}$ according to the time scale of McDougall (1977).

At Hole 516A, the Pliocene section extends from foraminiferal Zone PL1 to PL5 (Fig. 3). A hiatus occurs within Section 516A-3-2, resulting in the loss of Zone PL6. This gap is indicated by the occurrence of a PL5 fauna including Globorotalia miocenica and G. exilis in Sample 516A-3-2, 50-52 cm, immediately followed by the first appearance datum (FAD) of the Pleistocene species $G$. truncatulinoides in Sample 516A-3-2, 20-22 cm (Berggren, Aubry, and Hamilton, this volume).

The top of paleomagnetic Chron 5, equivalent to the Miocene/ Pliocene boundary, was used to calculate sedimentation rates within Zone PL1a. Placement of the top of Chron 5 at $50.4 \mathrm{~m}$ subbottom is based on the absence of one Gilbert normal event as indicated by both the polarity reversals and on the generalized biostratigraphic placement of the Miocene/Pliocene boundary (Hamilton and Suzyumov, in press). The time scale at Site 517 is based solely on the foraminiferal biostratigraphy and covers the period from planktonic foraminiferal Zone PL3 to the Pliocene/Pleistocene boundary (Fig. 4). The foraminiferal assemblages indicate no disruption.

\section{RESULTS}

\section{Pliocene Planktonic Oxygen Isotopic Record of Holes 516A and 517}

The planktonic isotopic records from Holes 516A and 517 are plotted together against time in order to provide a history of the Pliocene from approximately 4.6 to $1.8 \mathrm{Ma}$ (Fig. 5). Some uncertainty in correlation exists between the planktonic isotopic records from Holes 516A and 517 (Fig. 5), most probably because of the limited resolution of the biostratigraphically derived time scale. Possibly, shifting the curves $\pm 100,000$ years would improve the observed correlations. Undetected hiatuses and some subjectivity in determination of biostratigraphic zonal boundaries may also contribute to the apparent inconsistencies between Holes 516A and 517. The data can be described in terms of general trends and specific isotopic events. A series of low-amplitude fluctuations characterize the base of the $\delta^{18} \mathrm{O}$ record. This trend is interrupted by an ${ }^{18} \mathrm{O}$ enrichment of $0.55 \%$ from approximately 4.5 to $4.3 \mathrm{Ma}$. A gradual enrichment of $0.5 \%$ begins at $3.9 \mathrm{Ma}$ and is followed by a depletion of the same magnitude. A change in the character of the record occurs at approximately 3.2 Ma, when more rapid variations in isotopic composition occur in contrast to the gradual, long-term trends before 3.2 Ma. Two positive isotopic events of $0.65 \%$ and $0.4 \%$ occur at 2.7 and $2.4 \mathrm{Ma}$, respectively. The remaining section of the $\delta^{18} \mathrm{O}$ curve exhibits variations of $\sim 0.15 \%$, resulting in a very stable late Pliocene record.

\section{Pliocene Planktonic Carbon Isotopic Record of Holes 516A and 517}

The early Pliocene exhibits a $1.0 \%$ depletion in ${ }^{13} \mathrm{C}$ from approximately 4.6 to $3.9 \mathrm{Ma}$. This trend ends in an abrupt negative shift of $0.7 \%$ (Fig. 5). After this event, the $\delta^{13} \mathrm{C}$ values are relatively constant, but remain less than those before the shift. A second abrupt depletion of $0.6 \%$ occurs at approximately $3.3 \mathrm{Ma}$. The subsequent values for Hole 516A also remain of fset relative to those before the event. The remainder of the $\delta^{13} \mathrm{C}$ 


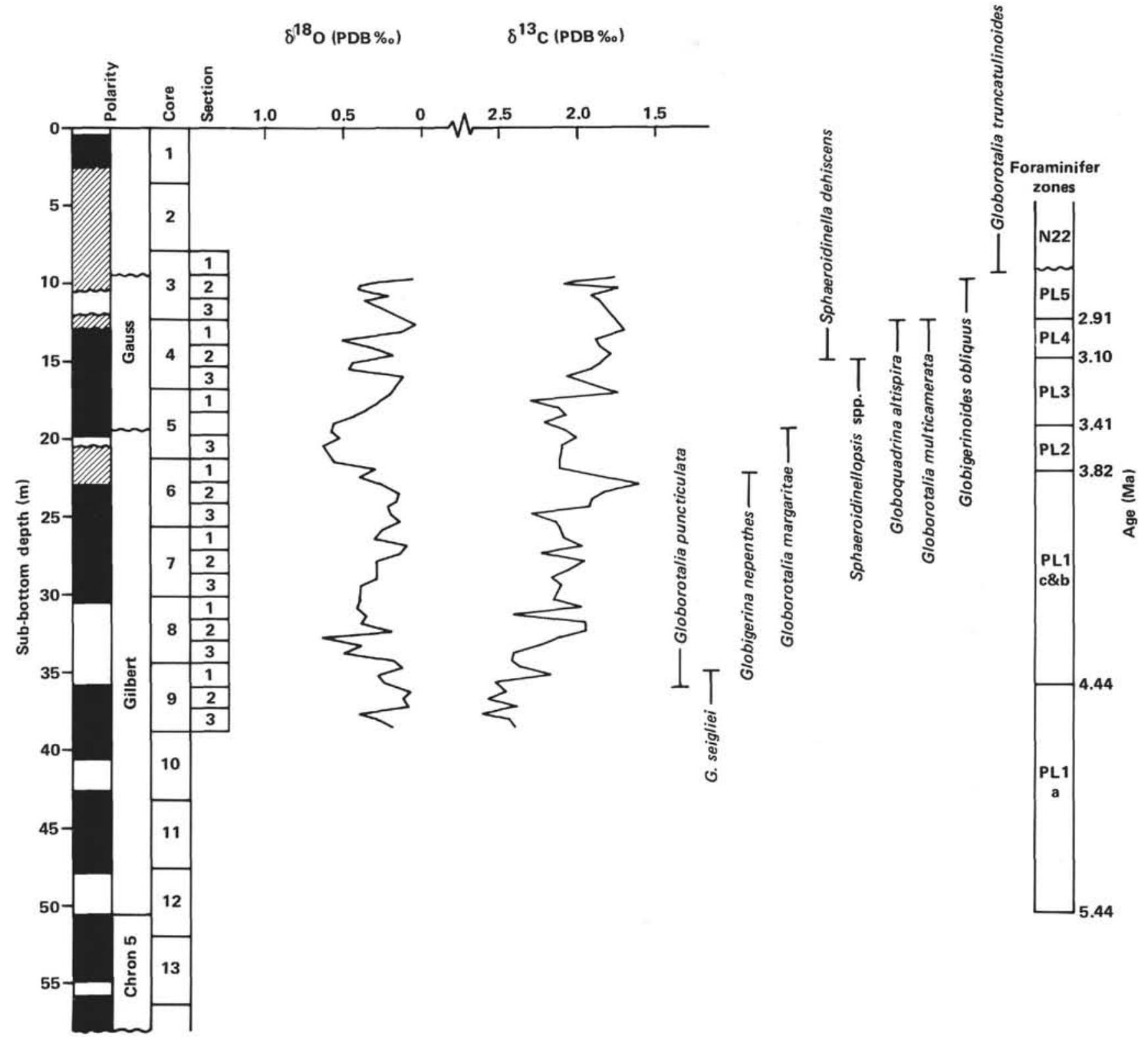

Figure 3. The $\delta^{18} \mathrm{O}$ and $\delta^{13} \mathrm{C}$ values for the planktonic foraminiferal species Globigerinoides sacculifer. The biostratigraphic zonation is based on planktonic foraminifers, and the paleomagnetic zones were interpreted from the magnetic polarity reversals (Hamilton and Suzyumov, this volume) plotted to sub-bottom depth for DSDP Hole 516A. Areas of diagonal lines in polarity logs indicate intervals for which polarity was unclear.

curve exhibits fluctuations on the order of $0.5 \%$ or less, with no net change.

\section{Pliocene Benthic Isotopic Record of Hole 516A}

Several trends and events are evident in the oxygen isotopic record of Cibicides wuellerstorfi (Fig. 6). This record is initially characterized by a sharp enrichment of $0.75 \%$ at approximately $4.4 \mathrm{Ma}$., followed by a longterm depletion of $1.15 \%$ ending at approximately 4.1 Ma (Fig. 6). An oscillatory increase in $\delta^{18} \mathrm{O}$ of $0.55 \%$ occurs from 4.1 to approximately $3.8 \mathrm{Ma}$. Fluctuations of $0.35 \%$ and less characterize the $\delta^{18} \mathrm{O}$ record from 3.8 to $3.4 \mathrm{Ma}$. A trend towards enrichment in ${ }^{18} \mathrm{O}$ begins at approximately 3.4 to $3.2 \mathrm{Ma}$. This trend offsets the remaining $\delta^{18} \mathrm{O}$ values from those earlier in the Pliocene.
The top of the Hole 516A record (from approximately $2.8 \mathrm{Ma}$ ) contains one light value at the onset of higheramplitude fluctuations of 0.65 to $0.75 \%$.

The carbon isotopic record of $C$. wuellerstorfi appears to be relatively stable, fluctuating about a mean of $0.79 \%$, but several events can be observed (Fig. 6). The earliest significant $\delta^{13} \mathrm{C}$ event is an abrupt negative peak centered at approximately $4.4 \mathrm{Ma}$. After this peak, the $\delta^{13} \mathrm{C}$ values decrease $0.45 \%$ over a period of approximately 380,000 years. A relatively stable section of the record ends in a well-defined enrichment peak at approximately $3.7 \mathrm{Ma}$. This peak is followed by three events of similar character. The first is an enrichment of $0.5 \%$ over approximately 250,000 years, ending in an abrupt depletion of the same magnitude. Immediately 


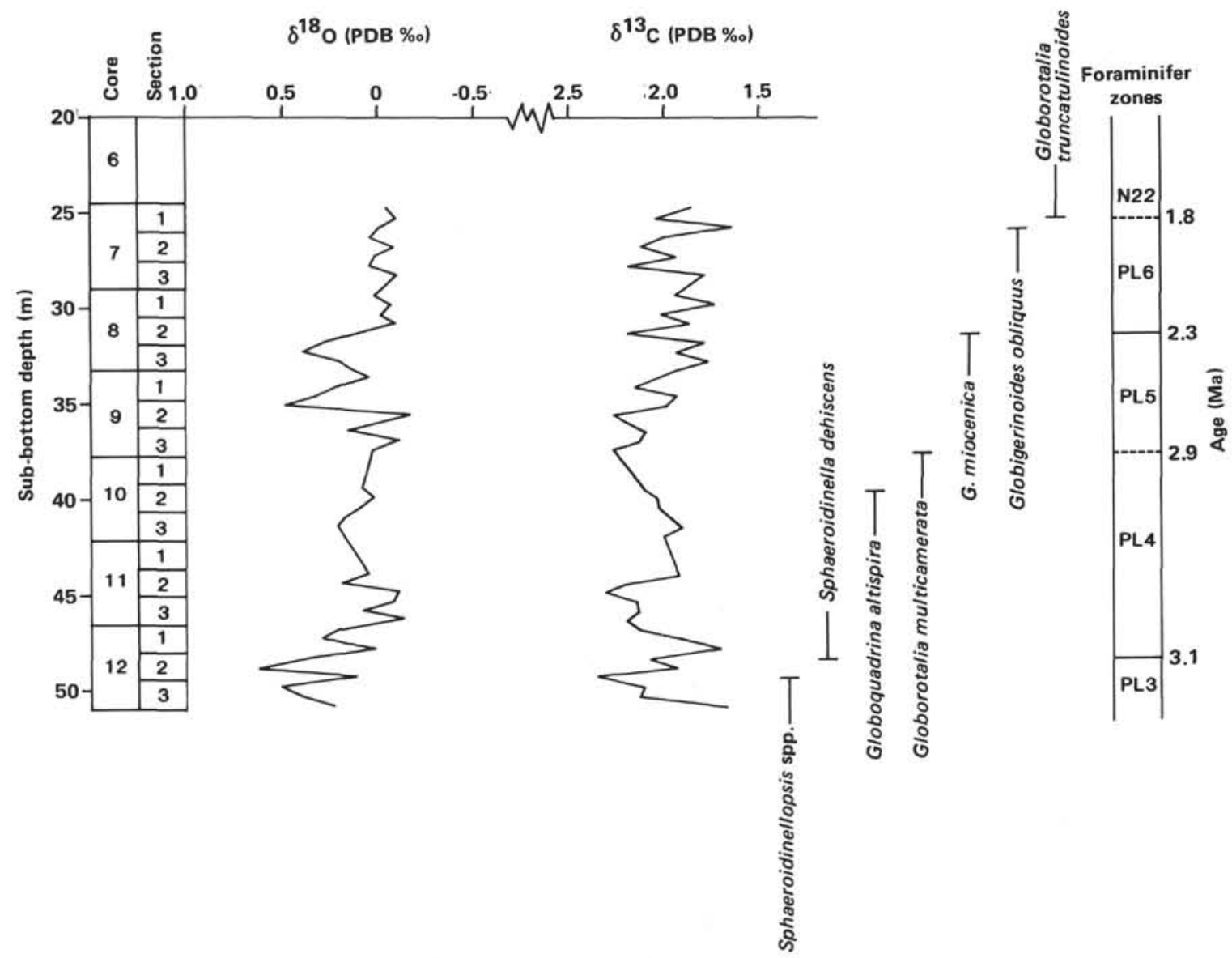

Figure 4. The $\delta^{18} \mathrm{O}$ and $\delta^{13} \mathrm{C}$ values for the planktonic foraminiferal species Globigerinoides sacculifer and the biostratigraphic zonation for Site 517 based on planktonic foraminifers plotted against sub-bottom depth.

after this abrupt shift, there is a second enrichment, which terminates in an abrupt depletion of approximately $0.5 \%$. This relationship, an abrupt depletion preceded by a more gradual enrichment, is repeated a third time at approximately 3.1 Ma. The remaining section of the $\delta^{13} \mathrm{C}$ record is relatively stable until it ends in a sharp negative peak centered at $2.7 \mathrm{Ma}$.

The absolute differences between the $\delta^{18} \mathrm{O}$ values $\left(\Delta^{18} \mathrm{O}\right)$ and the $\delta^{13} \mathrm{C}$ values $\left(\Delta^{13} \mathrm{C}\right)$ of $C$. wuellerstorfi and Globigerinoides sacculifer were determined. Increasing and decreasing values of $\Delta^{18} \mathrm{O}$ and $\Delta^{13} \mathrm{C}$ should reflect differences and similarities, respectively, between intermediate and surface-water $\delta^{18} \mathrm{O}$ and $\delta^{13} \mathrm{C}$ values through time. The $\Delta^{18} \mathrm{O}$ record (Fig. 7) is predominantly influenced by variations in benthic $\delta^{18} \mathrm{O}$ record. Benthic and planktonic carbon records, however, show a somewhat greater covariance than the oxygen isotopic records (Fig. 6). Both $\delta^{13} \mathrm{C}$ records exhibit a gradual depletion in ${ }^{13} \mathrm{C}$ that occurred during the early Pliocene. This covariance is punctuated by two abrupt planktonic depletions of approximately $0.73 \%$ and $0.75 \%$. It seems that, between approximately 3.5 and $3.2 \mathrm{Ma}$, the benthic and planktonic $\delta^{18} \mathrm{O}$ values varied out of phase. After this, changes in $\Delta^{13} \mathrm{C}$ are dominated by the greater magnitude of the benthic isotopic fluctuations. These changing relationships between and planktonic $\delta^{13} \mathrm{C}$ values $\left(\Delta^{13} \mathrm{C}\right)$ may be related to variations in water mass properties, boundaries throughout the Pliocene, or both.

\section{DISCUSSION}

\section{Pliocene Paleoclimatic History Interpreted from Oxygen Isotopes}

Pliocene paleoclimatic trends and events are inferred from the $\delta^{18} \mathrm{O}$ records of benthic and planktonic foraminifers. The oxygen isotopic results from Cibicides wuellerstorfi and Globigerinoides sacculifer of Hole $516 \mathrm{~A}$ do not correlate well. In some instances, they are in phase, in others out of phase, and often the relationship appears to be random. This pattern suggests that many times during the middle to late Pliocene, the oxygen isotopic composition of planktonic foraminifers was influenced by factors other than ice volume, such as changing sea-surface temperatures or salinity variations (other than those related to changing glacial ice volume).

Planktonic $\delta^{18} \mathrm{O}$ values are generally considered to be more variable than benthic $\delta^{18} \mathrm{O}$ because of the more frequent fluctuations in regional and global surfacewater temperatures. Modern benthic $\delta^{18} \mathrm{O}$ values are subject to less of a temperature effect because of the more constant temperatures of intermediate and deepwater masses. Therefore, the $\delta^{18} \mathrm{O}$ record of $C$. wueller- 


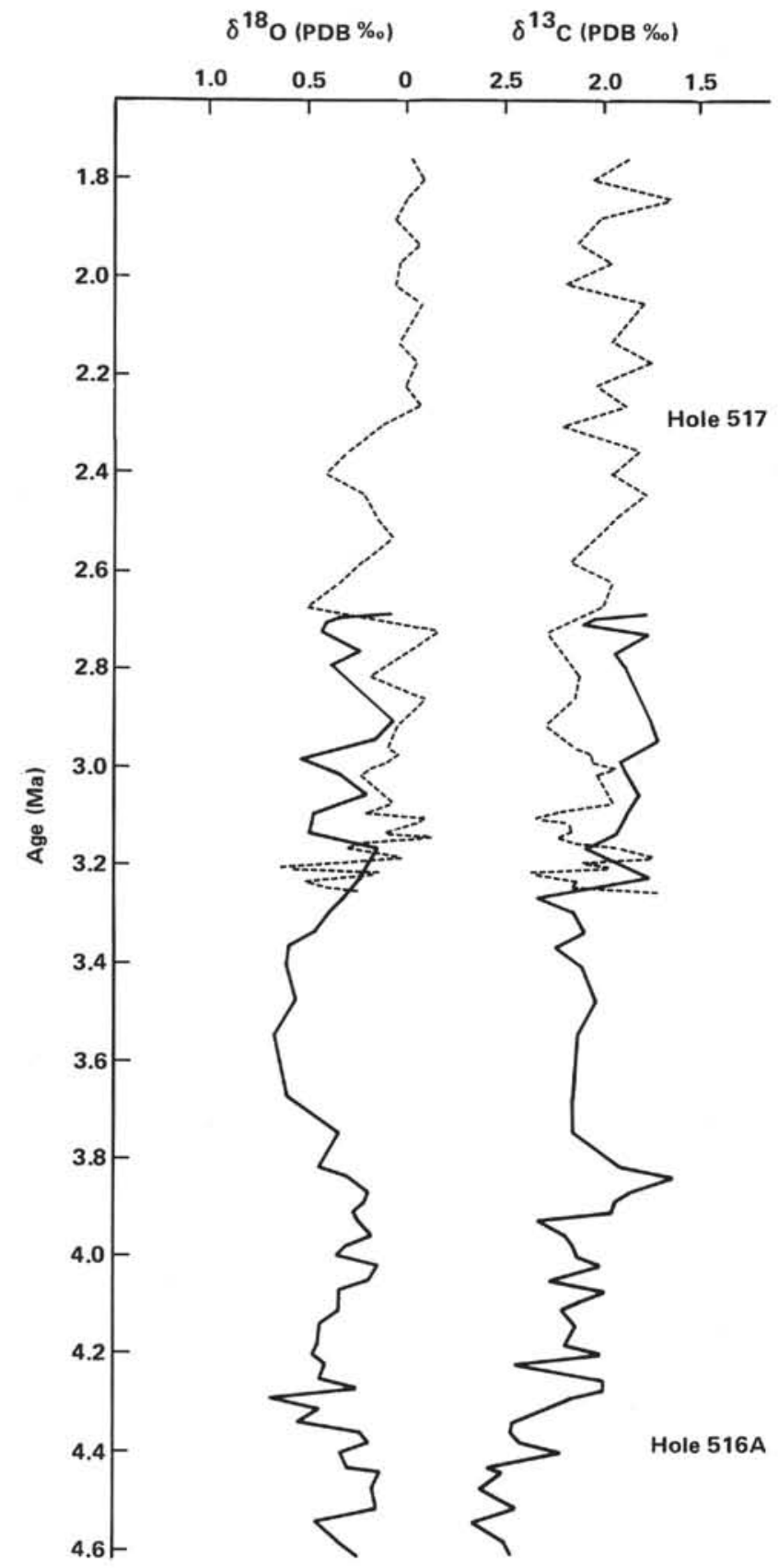

Figure 5. The planktonic oxygen and carbon isotopic records of Globigerinoides sacculifer at DSDP Holes 516A (solid line) and 517 (dotted line) spliced together based on extrapolation of constant sedimentation rates between planktonic biostratigraphic zones.

storfi at Hole 516A should be a reliable indicator of the glacial/interglacial climatic events from 4.6 to $2.7 \mathrm{Ma}$, although bottom temperature changes may play a small role in older $\delta^{18} \mathrm{O}$ records.

One of the most obvious series of events in the benthic $\delta^{18} \mathrm{O}$ record is the sharp, positive peak $(0.75 \%$ ) centered at approximately $4.4 \mathrm{Ma}$ (Fig. 6), followed by a decrease in $\delta^{18} \mathrm{O}$ of approximately $1.15 \%$ ending at $4.1 \mathrm{Ma}$. Oscillations of 0.25 to $0.55 \%$ are superimposed over this decrease. This series of events was possibly related to gla- cial fluctuations in the Antarctic ice cap. The east Antarctic ice sheet began forming at approximately $14 \mathrm{Ma}$, and both the east and west Antarctic ice sheets were established by $7 \mathrm{Ma}$ (Mercer, 1978; Woodruff et al., 1981). The positive peaks centered at 3.7 and $3.5 \mathrm{Ma}$ may be related to one of the first Patagonian glaciations (3.5 Ma) (Mercer, 1976), which may have been associated with an Antarctic glacial advance. This enrichment in ${ }^{18} \mathrm{O}$ is also reflected in the planktonic data by the increase in $\delta^{18} \mathrm{O}$ between approximately 3.7 and $3.5 \mathrm{Ma}$.

A significant planktonic event occurs from approximately 3.5 to $3.2 \mathrm{Ma}$, where a depletion of $0.5 \%$ occurs. This event does not correlate with the benthic "ice volume" record, which suggests that the planktonic event is possibly related to regional changes effected by restriction of surface equatorial circulation caused by the emergence of the Panama isthmus at approximately $3.5 \mathrm{Ma}$ (Berggren and Hollister, 1977).

The benthic trend towards increasing $\delta^{18} \mathrm{O}$ values, which begins at approximately $3.2 \mathrm{Ma}$, probably reflects the initiation of permanent northern hemisphere glaciation (Shackleton and Opdyke, 1977; Shackleton and Cita, 1979). Beginning at approximately $2.8 \mathrm{Ma}$, according to the benthic $\delta^{18} \mathrm{O}$ record, there occurred two higher-frequency, higher-amplitude $(0.7 \%$ ) glacial/interglacial fluctuations, which are analogous to the increase in scale of the glacial events characteristic of the late Pliocene (Shackleton and Opdyke, 1977).

The planktonic oxygen isotopic record of Hole 516A does not have the same features as the benthic isotope record since $3.2 \mathrm{Ma}$. (Fig. 6). The nature of the $\delta^{18} \mathrm{O}$ events changes from the more gradual trends immediately preceding $3.2 \mathrm{Ma}$ to more rapid changes in $\delta^{18} \mathrm{O}$ after, but no significant offset or enrichment in ${ }^{18} \mathrm{O}$ is recorded. In Hole 517, two events of higher amplitude occur at approximately 2.7 and $2.4 \mathrm{Ma}$ in an otherwise stable late Pliocene section (Fig. 5). In the remainder of the planktonic record (from 2.3 to $1.8 \mathrm{Ma}$ ) $\delta^{18} \mathrm{O}$ variations are $0.15 \%$ or less, resulting in a very stable late Pliocene section.

At Site 517 , the expected ${ }^{18} \mathrm{O}$ enrichment that occurred during the late Pliocene and was caused by the initiation of northern hemisphere glaciation is not observed, possibly because of a slight surface-temperature increase in the region of the Rio Grande Rise resulting in an ${ }^{18} \mathrm{O}$ depletion. The two major factors that influence the isotopic composition of foraminiferal calcite, the isotopic composition of seawater (which is related to salinity) and the temperature of seawater, are apparently acting in opposite directions at this time, resulting in a stable $\delta^{18} \mathrm{O}$ record.

Dampening of the late Pliocene isotopic signal at Site 517 may perhaps be explained by the interaction of the orbital parameters and their effects on ocean warming and glacial ice volumes. The distribution of incoming solar radiation is predominantly controlled by the three orbital variables: precession of the equinoxes, obliquity (tilt of the earth's axis), and eccentricity (the ellipticity of the earth's orbit). The growth and decay of continental ice sheets are dependent on the amount and the dis- 


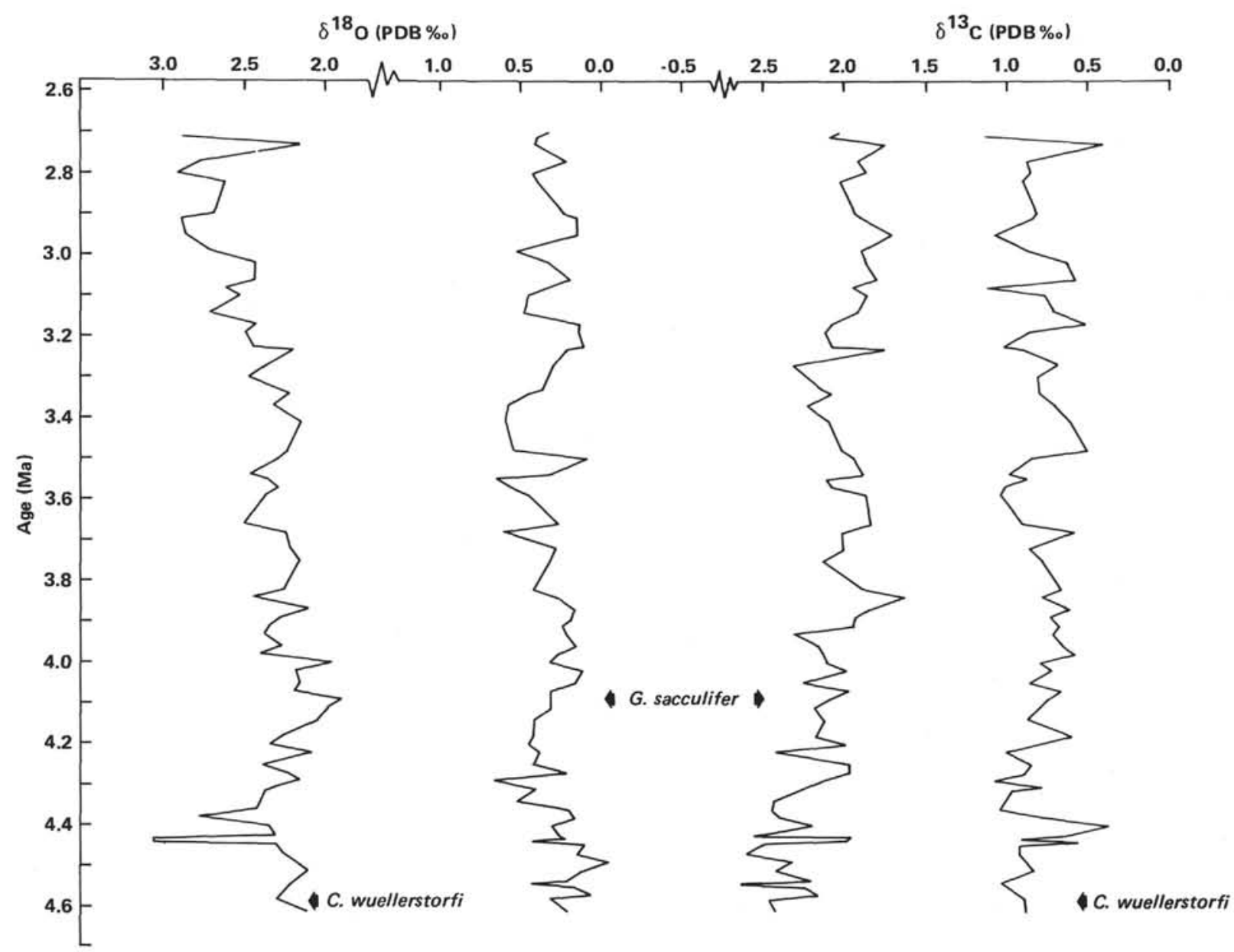

Figure 6. The $\delta^{18} \mathrm{O}$ and $\delta^{13} \mathrm{C}$ values for Cibicides wuellerstorfi and Globigerinoides sacculifer plotted against time for Hole 516A. The time scale for Hole 516A was derived through extrapolation of constant sedimentation rates between biostratigraphic zones.

tribution of summer insolation at high latitudes, where the ice accumulates, and are therefore a function of orbital variations (Hays et al., 1976). Periods of decreased seasonal contrast (cool summers and warm winters) favor the buildup of glacial ice. Because the precessional cycle is out of phase between the northern and southern hemispheres, times of reduced seasonal contrast in the north are times of increased seasonal contrast in the south (warm summers and cold winters) (Broecker and van Donk, 1970). This combination may actually result in a warming of mid-latitude southern hemisphere surface waters during periods of northern hemisphere glacial ice buildup and climatic cooling.

The CLIMAP (1976) reconstructions (comparing modern sea-surface temperatures to those of the glacial maximum 18,000 years ago) support the hypothesis that mid-latitude southern hemisphere surface waters became warmer during northern hemisphere glacial events. In these reconstructions, several areas in the southern hemisphere, including the area of the Rio Grande Rise, exhibit temperature anomalies. Surface-water temperatures in the vicinity of the Rio Grande Rise either remained at their warm interglacial values or increased during the last increase in northern hemisphere ice volume at the glacial maximum.

\section{Pliocene Paleoceanographic Events Related to Carbon Isotopes}

Variations in the degree of similarity or difference between the $\delta^{18} \mathrm{O}$ of benthic and planktonic foraminifers at Hole 516A may reflect changes in the $\delta^{18} \mathrm{O}$ of intermediate and/or surface water masses as well as changes in the positions of transition zones between particular water masses. The location of DSDP Site 516 within an area of strong hydrographic gradients (especially $\delta^{13} \mathrm{C}$ gradient) at the transition between AAIW and CPW should make it a sensitive indicator of variations associated with these two water masses. Because of the existence of a strong $\delta^{13} \mathrm{C}$ gradient at Site 516 , only changes in $\delta^{13} \mathrm{C}$ of $0.4 \%$ and greater are considered to reflect significant changes in water masses.

The core of NADW at approximately $3000 \mathrm{~m}$ depth presently has a $\delta^{13} \mathrm{C}$ maximum of $>1.0 \%$ relative to PDB (Fig. 2). The core of CPW presently records a $\delta^{13} \mathrm{C}$ minimum of $<0.2 \%$ between 1300 and $1700 \mathrm{~m}$ depth at approximately $50^{\circ} \mathrm{S}$ latitude. The $\delta^{13} \mathrm{C}$ at Hole 516A approximated from GEOSECS data (Kroopnick, 1980a) is $0.65 \%$ at a depth of approximately $1300 \mathrm{~m}$ and $1.8 \%$ at $50 \mathrm{~m}$, the calcification depth of Globigerinoides sacculifer. These values reflect an average modern $\Delta^{13} \mathrm{C}$ of 
approximately $1.15 \%$. The average Pliocene $\Delta^{13} \mathrm{C}$ is equal to $1.29 \pm 0.26 \%$. Because this is within the range of modern values, it can be assumed that the distribution of $\delta^{13} \mathrm{C}$ in the Pliocene South Atlantic was similar to the modern distribution. This assumption is also supported by sedimentologic, faunal, and other isotopic evidence that modern intermediate and deep circulation patterns were established by the early Pliocene and that modern surface circulation became fully established during the mid-Pliocene (Berggren and Hollister, 1977; Keigwin, 1982).

Evidence from core-top samples suggests that the distribution of the $\delta^{13} \mathrm{C}$ of dissolved bicarbonate in seawater is reflected in the $\delta^{13} \mathrm{C}$ distribution in foraminifers. Belanger and others (1981) and Graham and others (1981) present evidence that $\delta^{13} \mathrm{C}$ values of Cibicides wuellerstorfi exhibit a consistent offset from the $\delta^{13} \mathrm{C}$ of dissolved bicarbonate; therefore, this species may be useful in determining relative changes in the $\delta^{13} \mathrm{C}$ of seawater $\mathrm{HCO}_{3}^{-}$. Data from Curry and Lohman (1982) and Williams and Healy-Williams (1982) indicate that the $\delta^{13} \mathrm{C}$ of benthic foraminifers has trends similar to the $\delta^{13} \mathrm{C}$ of $\mathrm{HCO}_{3}^{-}$within water masses and across water mass boundaries within the Vema Channel. These studies suggest that changes in $\Delta^{13} \mathrm{C}$ based on the carbon iso- topic composition of foraminifers should reflect changes in the distribution of $\delta^{13} \mathrm{C}$ and therefore changes in water mass properties or patterns through time.

A number of the significant $(>0.4 \% 0) \Delta \Delta^{13} \mathrm{C}$ events at Hole 516A (Fig. 7) can be explained by a combination of several events, such as variations in circulation rates, differing rates of production of particular water masses, stratification of the water column, or changes in the $\Delta^{13} \mathrm{C}$ of oceanic $\mathrm{HCO}_{3}^{-}$. Several of the $\Delta^{13} \mathrm{C}$ events are better understood by examination of the relative isotopic changes in individual benthic and planktonic $\delta^{13} \mathrm{C}$ records (Fig. 6). Rapid negative changes in the planktonic $\delta^{13} \mathrm{C}$ record in the early Pliocene (at approximately 4.3-4.2 and 3.9-3.8 Ma), which do not appear in the benthic $\delta^{13} \mathrm{C}$ record, most probably reflect times when the intermediate and surface waters became more similar in isotopic composition.

The above situation, in which the planktonic $\delta^{13} \mathrm{C}$ record approaches the benthic record with only minor variations recorded by the benthic data, could be related to decreased stratification in the surface waters. This might occur as a result of increased upwelling of intermediate waters having lower $\delta^{13} \mathrm{C}$ values (Kroopnick, $1980 \mathrm{a}, \mathrm{b})$. Upwelling of waters more depleted in ${ }^{13} \mathrm{C}$ should result in a decrease in the $\delta^{13} \mathrm{C}$ values of the

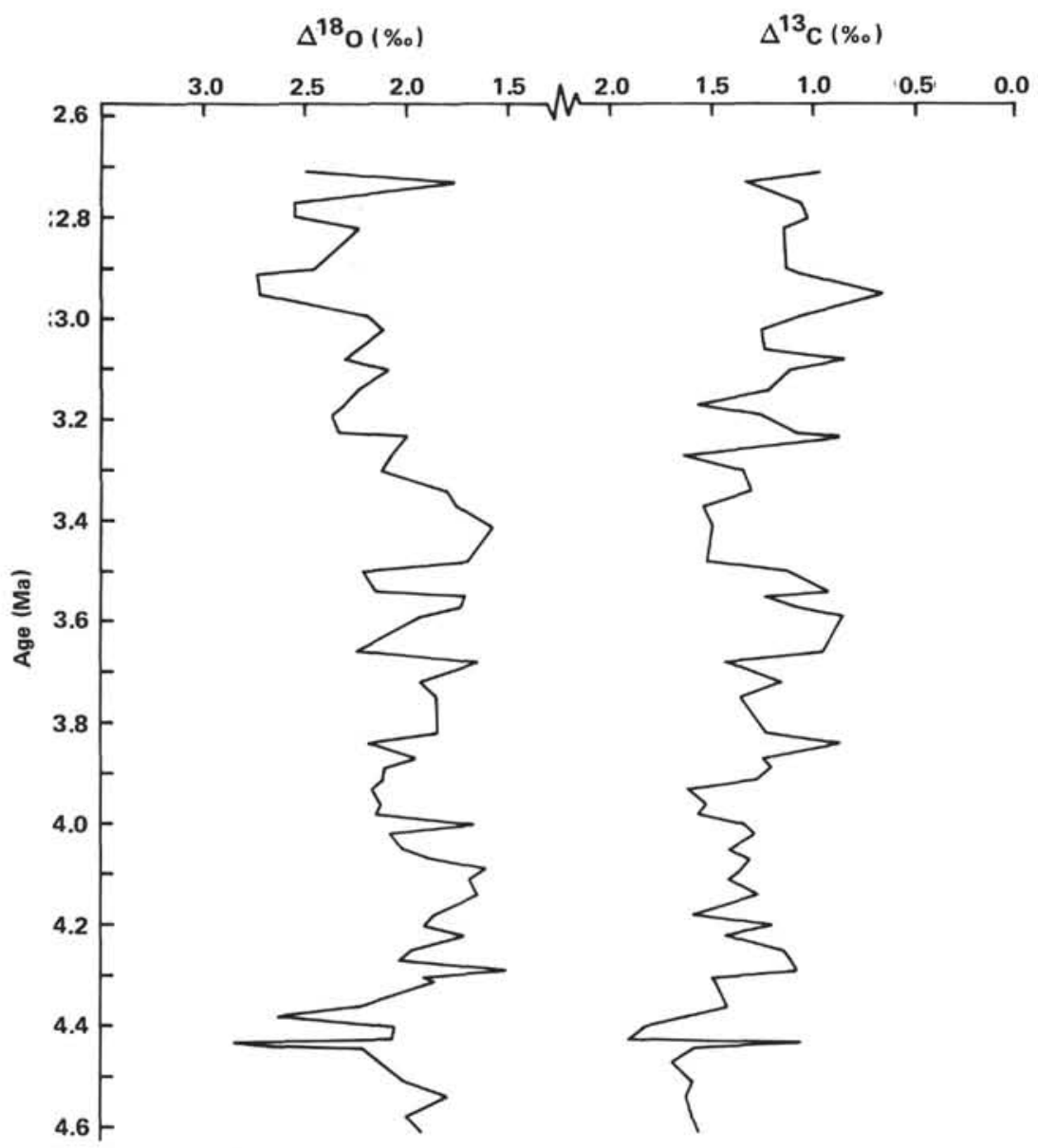

Figure 7. The difference between planktonic and benthic $\delta^{18} \mathrm{O}$ values $\left(\Delta^{18} \mathrm{O}\right)$ and the difference between planktonic and benthic $\delta^{13} \mathrm{C}$ values $\left(\Delta^{13} \mathrm{C}\right)$ at Hole $516 \mathrm{~A}$ plotted against time. 
planktonic foraminifers. The paleoceanographic event closest in time to the first rapid ${ }^{13} \mathrm{C}$ depletion at approximately $4.43 \mathrm{Ma}$ is the pronounced northward shift of the Antarctic convergence that occurred in the early Pliocene (Berggren and Hollister, 1977). There is a possibility that this event had an effect on oceanic mixing rates, which in turn led to increased upwelling.

The initiation of northern hemisphere glaciation at 3.2 $\mathrm{Ma}$ (as indicated by the oxygen isotopes) is accompanied by an increased difference between benthic and planktonic $\delta^{13} \mathrm{C}$ values mostly because of a $0.5 \%$ decrease in the benthic record. There is evidence that rates of NADW production may have decreased during northern hemisphere glacial events of the late Pleistocene, resulting in sluggish Atlantic circulation (Streeter and Shackleton, 1979; Boyle, 1981). In this case, there would be two ways to decrease the $\delta^{13} \mathrm{C}$ at the transition between CPW and AAIW. First, if circulation rates decreased because of decreased production of NADW, then each water mass would be an "older" water mass at any given site. Because of the effects of respiration and organic matter oxidation, an older water mass will have a lower $\mathrm{O}_{2}$ content and a greater $\mathrm{CO}_{2}$ concentration with more negative $\delta^{13} \mathrm{C}$ values. Secondly, with decreased NADW production, the CPW might expand to greater depths and lower latitudes. CPW is depleted in ${ }^{13} \mathrm{C}$; therefore, its expansion should carry water with lower $\delta^{13} \mathrm{C}$ values further north into the area of Hole $516 \mathrm{~A}$ at $1313 \mathrm{~m}$.

After this first response to the initiation of northern hemisphere glaciation at $3.2 \mathrm{Ma}$, a negative trend in planktonic $\delta^{13} \mathrm{C}$ is reflected in a trend towards more similar $\Delta^{13} \mathrm{C}$ values throughout the late middle Pliocene. This increased similarity could be a response to the expansion of the Antarctic water masses (CPW and AAIW) during the contraction of NADW, which in turn may have resulted in decreased water column stratification and increased upwelling of ${ }^{13} \mathrm{C}$-depleted waters. Surface waters more depleted in ${ }^{13} \mathrm{C}$ would thus be reflected in the carbon isotopic composition of Globigerinoides sacculifer.

\section{SUMMARY AND CONCLUSIONS}

Comparison of oxygen and carbon isotopic records of benthic and planktonic foraminifers from DSDP Hole 516A reveals general paleoclimatic and paleoceanographic trends that occurred on the Rio Grande Rise during the Pliocene. The first trend is a series of variations in $\delta^{18} \mathrm{O}$ inferred to be related to variations in the Antarctic ice cap throughout the early to middle Pliocene. The second is the initiation of northern hemisphere glaciation at approximately 3.2 Ma. This event exhibits the characteristic net ${ }^{18} \mathrm{O}$ enrichment after the initiation, as well as the previously observed increase in scale of the later Pliocene glacial/interglacial events at approximately $2.8 \mathrm{Ma}$ (Shackleton and Opdyke, 1977).

After the initiation of northern hemisphere glaciation at $3.2 \mathrm{Ma}$, the planktonic $\delta^{18} \mathrm{O}$ record contrasts with the benthic record. The net depletion and dampened isotopic signal reflected in the isotopic composition of Globigerinoides sacculifer may be related to increased surface- water temperatures in middle southern latitudes during northern hemisphere glacial ice buildup. The reciprocal influences of the orbital parameters on oceanic temperatures and glacial ice growth and decay between the two hemispheres may be recorded by the net depletion and low-amplitude fluctuations of the late Pliocene $\delta^{18} \mathrm{O}$ record.

The $\delta^{13} \mathrm{C}$ record at Hole 516A reflects times of increased or decreased similarity between CPW and surface water $\delta^{13} \mathrm{C}$ values, which may be associated with paleoclimatic events. For example, at approximately $3.2 \mathrm{Ma}$, a decrease in the difference in $\delta^{13} \mathrm{C}$ between intermediate and surface waters is reflected in ${ }^{13} \mathrm{C}$ depletion of benthic foraminifers. This could be related to decreased production of NADW causing sluggish Atlantic circulation and a contraction of the core of NADW. Diminished NADW production would allow the expansion of CPW, which would introduce waters lower in $\delta^{13} \mathrm{C}$ into the area of Hole 516A. The oxygen and carbon isotopic records of Holes 516A and 517 allow for the discrimination between global paleoclimatic events and regional paleoceanographic events that influenced the distribution of intermediate water masses within the southwestern Atlantic Ocean during the Pliocene.

\section{ACKNOWLEDGMENTS}

The authors would like to thank Michael Arthur, Richard Fillon, Lloyd Keigwin, and Warren Prell for constructive criticism of the manuscript; David Johnson for assistance in obtaining the samples for this study; and Joyce Goodwin and Donna Black for typing the manuscript in its various forms. This research was supported by National Science Foundation Grants OCE $80-08239$ and DPP $80-23696$. This is contribution number 493 of the Belle W. Baruch Institute for Marine Biology and Coastal Research.

\section{REFERENCES}

Belanger, P. E., Curry, W. B., and Matthews, R. K., 1981. Core-top evaluation of benthic foraminiferal isotopic ratios for paleooceanographic interpretations. Palaeogeogr. Palaeoclimatol. Palaeoecol., 33:205-220.

Bender, M. L., and Keigwin, L. D., Jr., 1979. Speculations about the upper Miocene change in abyssal Pacific dissolved bicarbonate $\delta^{13} \mathrm{C}$. Earth Planet. Sci. Lett., 45:383-393.

Berggren, W. A., 1977. Late Neogene planktonic foraminiferal biostratigraphy of the Rio Grande Rise (South Atlantic). Mar. Micropaleontol., 2:265-313.

Berggren, W. A., and Hollister, C. D., 1977. Plate tectonics and paleocirculation-commotion in the ocean. Tectonophysics, 38(1-2): $11-48$.

Blattner, P., and Hulston, J. R., 1978. Proportional variations of geochemical $\delta^{18} \mathrm{O}$ scales-an interlaboratory comparison. Geochim. Cosmochim. Acta, 42-59.

Broecker, W. S., 1982. Glacial to interglacial ocean chemistry during glacial time. Geochim. Cosmochim. Acta, 46:1689-1705.

Broecker, W. S., and Takahashi, T., 1980. Hydrography of the central Atlantic. III. The North Atlantic deep-water complex. DeepSea Res., 27A:591-613.

Broecker, W. S., and van Donk, J., 1970. Insolation changes, ice volumes, and the ${ }^{18} \mathrm{O}$ record in deep sea cores. Rev. Geophys. Space Phys., 8:169.

CLIMAP Project Members, 1976. The surface of ice-age earth. Science, 191:1131-1137.

Craig, H., 1957. Isotopic standards for carbon and oxygen and correction factors for mass-spectrometric analysis of carbon dioxide. Geochim. Cosmochim. Acta, 12:122.

Curry, W. B., and Lohmann, G. P., 1982. Carbon isotopic changes in benthic foraminifera from the western South Atlantic: reconstruction of glacial abyssal circulation patterns. Quat. Res., 18:218-235. 
Duplessy, J. C., Moyes, J., and Pujol, C., 1980. Deep water formation in the North Atlantic Ocean during the last ice age. Nature, 286:479-482.

Emiliani, C., 1955. Pleistocene paleotemperatures. J. Geol., 63:538. 1966. Isotopic paleotemperatures. Science, 154:851.

Francheteau, J., and LePichon, X., 1972. Marginal fracture zones as structural framework of continental margins in South Atlantic Ocean. Am. Assoc. Pet. Geol. Bull., 56:991-1007.

Goodney, D. E., Margolis, S. V., Dudley, W. C., Kroopnick, P., and Williams, D. F., 1980. Oxygen and carbon isotopes of recent calcareous nannofossils as paleoceanographic indicators. Mar. Micropaleontol., 5:31-42.

Haq, B. U., Berggren, W. A., and Van Couvering, J. A., 1977. Corrected age of the Pliocene/Pleistocene boundary. Nature, 269: 483-488.

Hays, J. D., Imbrie, J., and Shackleton, N. J., 1976. Variations in the earth's orbit: pacemaker of the ice ages. Science, 194:1121-1132.

Keigwin, L. D., Jr., 1978. Pliocene closing of the isthmus of Panama, based on biostratigraphic evidence from nearby Pacific Ocean and Caribbean Sea cores. Geology, 6:630-634.

1979. Late Cenozoic stable isotope stratigraphy and paleoceanography of DSDP sites from the east equatorial and central North Pacific Ocean. Earth Planet. Sci. Lett., 45:361-382.

1982. Isotopic paleoceanography of the Caribbean and east Pacific; role of Panama uplift in late Neogene time. Science., 217: 350-353.

Kroopnick, P., 1974. Correlations between ${ }^{13} \mathrm{C}$ and $\Sigma \mathrm{CO}_{2}$ in surface waters and atmospheric $\mathrm{CO}_{2}$. Earth Planet. Sci. Lett., 22:397-403. $1980 \mathrm{a}$. The distribution of ${ }^{13} \mathrm{C}$ in the Atlantic Ocean. Earth Planet. Sci. Lett., 49:469-484.

1980b. Isotopic fractionations during oxygen consumption and carbonate dissolution within the North Atlantic Deep Water. Earth Planet. Sci. Lett., 49:485-490.

McDougall, I., 1977. The Present Status of the Geomagnetic Polarity Time Scale: Canberra, A. C. T. (Research School for the Earth Sciences, Australian National University), Publ. No. 1288.

Mankinen, E. A., and Dalrymple, G. B., 1979. Revised geomagnetic polarity time scale for the interval 0-5 m.y.B.P. J. Geophys. Res., 84:615-626.

Mercer, J. H., 1976. Glacial history of southernmost South America. Quat. Res., 6:125-166.

1978. Glacial development and temperature trends in the Antarctic and in South America. In Van Zinderen Bakker, E. M. (Ed.), Antarctic Glacial History and World Paleoenvironments: Rotterdam (A. A. Balkema), pp. 73-93.

Reid, J. L., Nowlin, W. D., Jr., and Patzert, W. C., 1977. On the characteristics and circulation of the southwestern Atlantic Ocean. J. Phys. Oceanogr., 7:62-91.

Ruddiman, W. F., and McIntyre, A., 1981. Oceanic mechanisms for amplification of the 23,000-year ice-volume cycle. Science, 212: 617-627.

Ryan, W. B. F., Cita, M. B., Rawson, M. D., Burckle, L. H., and Saito, T., 1974. A paleomagnetic assignment of Neogene stage boundaries and the development of isochronous datum planes between the Mediterranean, the Pacific and Indian oceans in order to investigate the response of the world ocean to the Mediterranean salinity crisis. Riv. Ital. Paleontol., 80:631-687.
Saito, T., Burckle, L. H., and Hays, J. D., 1975. Late Miocene to Pleistocene biostratigraphy of equatorial Pacific sediments. In Saito, T., and Burckle, L. H. (Eds.), Late Neogene Epoch Boundaries: New York (Micropaleontology Press), pp. 226-234.

Savin, S. M., 1977. The history of the earth's surface temperature during the past 100 million years. Ann. Rev. Earth Planet. Sci., 5: 319-355.

Savin, S. M., Douglas, R. G., and Stehli, F. G., 1975. Tertiary marine paleotemperatures. Bull. Geol. Soc. Am., 86:1499-1510.

Scholle, P. A., and Arthur, M. A., 1980. Carbon isotopic fluctuations in Cretaceous pelagic limestones: potential stratigraphic and petroleum exploration tool. Am. Assoc. Pet. Geol. Bull., 64:67-87.

Shackleton, N. J., 1977. Carbon-13 in Uvigerina: Tropical rainforest history and the equatorial Pacific carbonate dissolution cycles. In Andersen, N. R., and Malahoff, A. (Eds.), The Fate of Fossil Fuel $\mathrm{CO}_{2}$ in the Oceans: New York (Plenum Press), pp. 401-427.

Shackleton, N. J., and Cita, M. B., 1979. Oxygen and carbon isotope stratigraphy of benthic foraminifers at Site 397: detailed history of climatic change during the late Neogene. In von Rad, U., Ryan, W. B. F., et al., Init. Repts. DSDP, 47, Pt. 1: Washington (U.S. Govt. Printing Office), 433-455.

Shackleton, N. J., and Kennett, J. P., 1975. Paleotemperature history of the Cenozoic and the initiation of Antarctic glaciation: oxygen and carbon isotope analyses in DSDP Sites 277,279 and 281 . In Kennett, J. P., Houtz, R. E., et al., Init. Repts. DSDP, 29: Washington (U.S. Govt. Printing Office), 743-756.

Shackleton, N. J., and Opdyke, N. D., 1977. Oxygen isotope and paleoclimatic evidence for early northern hemisphere glaciation. $\mathrm{Na}$ ture, 270:216-219.

Streeter, S. S., and Shackleton, N. J., 1979. Paleocirculation of the deep North Atlantic: 150,000-year record of benthic foraminifera and oxygen-18. Science, 203:168-171.

Thiede, J., 1977. Subsidence of aseismic ridges: evidence from sediments on Rio Grande Rise (southwest Atlantic Ocean). Am. Assoc. Pet. Geol. Bull., 61:929-940.

Thunell, R. C., 1981. Late Miocene-early Pliocene planktonic foraminiferal biostratigraphy and paleoceanography of low-latitude marine sequences. Mar. Micropaleontol., 6:71-90.

van Donk, J., 1976. ${ }^{18} \mathrm{O}$ record of the Atlantic Ocean for the entire Pleistocene Epoch. In Cline, R. M., and Hays, J. D. (Eds.), Investigation of Late Quaternary Palaeoceanography and Palaeoclimatology: Boulder, CO (Geol. Soc. Am. Mem.), 145:147-163.

Vincent, E., Killingley, J. S., and Berger, W. H., 1980. The magnetic Epoch-6 carbon shift: a change in ocean's ${ }^{13} \mathrm{C} /{ }^{12} \mathrm{C}$ ratio 6.2 million years ago. Mar. Micropaleontol., 5:185-203.

Williams, D. F., and Healy-Williams, N., 1982. Vertical isotope gradients in Recent benthic foraminifera and the water column of the Vema Channel. EOS, Trans. Am. Geophys. Union, 63:359.

Williams, D. F., Sommer, M. A., and Bender, M. L., 1977. Carbon isotopic compositions of recent planktonic foraminifera of the Indian Ocean. Earth Planet. Sci. Lett., 36:391-403.

Woodruff, F., Savin, S. M., and Douglas, R. G., 1981. Miocene stable isotope record: a detailed deep Pacific Ocean study and its paleoclimatic implications. Science, 212:665-668.

Date of Initial Receipt: July 2, 1982 